\title{
Wastewater treatment using integrated anaerobic baffled reactor and Bio-rack wetland planted with Phragmites sp. and Typha sp.
}

\author{
Shervin Jamshidi', Abbas Akbarzadeh², Kwang-Sung Woo ${ }^{3}$ and Alireza Valipour ${ }^{3^{*}}$
}

\begin{abstract}
The purpose of this study is to examine the potential use of anaerobic baffled reactor (ABR) followed by Bio-rack wetland planted with Phragmites sp. and Typha sp. for treating domestic wastewater generated by small communities (751 mg COD/L, $500 \mathrm{SCOD} \mathrm{mg/L,} 348 \mathrm{mg} \mathrm{BOD} / \mathrm{L}$ ). Two parallel laboratory-scale models showed that the process planted with Phragmites sp. and Typha sp. are capable of removing COD by $87 \% \& 86 \%$, SCOD by $90 \% \& 88 \%, \mathrm{BOD}_{5}$ by $93 \%$ \& $92 \%$, TSS by $88 \%$ \& $86 \%$, TN by $79 \%$ \& $77 \%, \mathrm{PO}_{4}-\mathrm{P}$ by $21 \%$ \& $14 \%$ at an overall HRT of $21\left(843 \mathrm{~g} \mathrm{COD} / \mathrm{m}^{3} /\right.$ day \& $392 \mathrm{~g} \mathrm{BOD}_{5} / \mathrm{m}^{3} /$ day) and $27\left(622 \mathrm{~g} \mathrm{COD} / \mathrm{m}^{3} /\right.$ day \& $302 \mathrm{~g} \mathrm{BOD}_{5} / \mathrm{m}^{3} /$ day) hours, respectively. Microbial analysis indicated a high reduction in the MPN of total coliform and TVC as high as $99 \%$ at the outlet end of the processes. The vegetated system using Phragmites sp. showed significantly greater $(p<0.05)$ pollutant removal efficiencies due to its extensive root and mass growth rate $(p<0.05)$ of the plant compared to Typha sp. The Phragmites sp. indicated a higher relative growth rate (3.92\%) than Typha sp. (0.90\%). Microorganisms immobilized on the surface of the Bio-rack media (mean TVC: $2.33 \times 10^{7} \mathrm{cfu} / \mathrm{cm}^{2}$ ) were isolated, identified and observed using scanning electron microscopy (SEM). This study illustrated that the present integrated processes could be an ideal approach for promoting a sustainable decentralization, however, Phragmites sp. would be more efficient rather than Typha sp.
\end{abstract}

Keywords: Anaerobic baffled reactor, Bio-rack wetland system, Phragmites sp, Typha sp, Domestic wastewater treatment

\section{Background}

Decentralized wastewater treatment systems (DEWATS) are appropriate for low-density communities and varying site conditions, and are more cost-effective than centralized practices. However, the efficiency of these systems depends on the attributes, and design criteria of the selected process [1]. Therefore, it is imperative to conduct research in order to develop a feasible and sustainable treatment technique for decentralization.

Anaerobic baffled reactor (ABR) reported to be a promising solution in domestic wastewater treatment [2-4]. The system recognized by incorporating the advantages of upflow anaerobic sludge blanket (UASB) and phase separation. It consists of alternating hanging and standing baffles, which compartmentalizes the reactor [5]. This practice leads the flow into intimate contact with the biomass [6,7],

\footnotetext{
* Correspondence: alirezavalipour.envi@gmail.com

${ }^{3}$ Department of Civil Engineering, Yeungnam University, Gyungsan, South Korea

Full list of author information is available at the end of the article
}

resulting in partial separation of acidogenesis and methanogenesis longitudinally down the reactor, and more stable operation [8-10]. It has been shown to provide higher resilience to hydraulic and organic shock loads, higher treatment rate, longer biomass retention times, and lower sludge yields than other anaerobic treatment systems [5]. Previous hydrodynamic studies revealed that the low dead space (7\% to $30 \%$ ) occurred in ABR [7]. Nasr et al. [2] reported removal efficiencies of $76 \%$ for total chemical oxygen demand $(\mathrm{COD})$, and $55 \%$ for biochemical oxygen demand $\left(\mathrm{BOD}_{5}\right)$ in ABR treating domestic wastewater at a hydraulic retention time (HRT) of 12 hours. Bodkhe [11] used a modified $\mathrm{ABR}$ in order to achieve $84 \% \mathrm{COD}$, and $87 \% \mathrm{BOD}_{5}$ in treating municipal wastewater at a HRT of 6 hours. Feng et al. [12] used a bamboo carrier ABR to treat sewage achieving $69 \%$ COD reduction at a HRT of 18 hours. Despite the significant advantages and efforts made worldwide, typically the effluent of ABR technique is totally nutrients rich, oxygen deficit, and containing high concentration of unacceptable pathogen [2]. This would surely deteriorate the quality 
of surface waters in rural areas. In fact, it requires post treatment for removing the remaining organic matters, nutrients and pathogens.

In the recent years, the application of constructed wetlands for wastewater treatment has received greater attention since they offer a cost effective and an environmentally sound approach [13]. In that order, the possible applications of integrated anaerobic pretreated-constructed wetlands have been introduced as a promising model for DEWATS [14-16]. The major mechanism associated in constructed wetland for pollutant removal is the interaction between the bacterial metabolism and plant uptake, respectively, termed as rhizoremediation and phytoextraction [17]. Plants transfer oxygen to their root system and release a fraction of this oxygen into the rhizosphere for aerobic bacterial activity [18]. The type of aquatic plant species can also act as an important biotic factor in the treatment efficiency of constructed wetlands [19]. In that order, among various aquatic weeds, Phragmites sp. and Typha sp. are two wellknown macrophytes demonstrated as potentially valuable vegetation in the natural purification process [20]. Nevertheless, the use of constructed wetlands, either as a standalone or combined solution, could be restricted by choking, clogging, slow mass transfer, poor root penetration into the multilayer soil column, high area requirement and capital investment. It is implied that conventional decentralized treatment processes are required to be optimized and upgraded to prevail over the limitations.

In our earlier recent work, the application of ABR has been studied comprehensively to optimize its design and operation in pollutant removal from domestic wastewater ( 350-750 mg COD/L), and it was simulated by artificial neural network $[9,10]$. On the other hand, the Bio-rack system (BRS) is one of the latest evolutions of wetland technologies that developed to overcome the drawbacks of conventional wetland processes [21]. This is a robust biological practice that can be applied to the efficient and reliable elimination of pollutants, even under unfavorable influent conditions stressed by high total dissolved solids and heavy metal [21,22]. Analytical data which collected during the treatment of domestic wastewater (COD $\leq 440$ $\mathrm{mg} / \mathrm{L}, \mathrm{BOD}_{5} \leq 238 \mathrm{mg} / \mathrm{L}$ ) showed that this process able to reduce up to $80 \% \mathrm{COD}$, and $90 \% \mathrm{BOD}_{5}$ at a HRT of 10 hours [21]. The process is designed by incorporating the advantages of engineered attached growth (using a support matrix of the Bio-racks) and phytoremediation systems. The Bio-rack technique provides a desirable condition for plant root growth, efficient oxygen diffusion, and a distinguished surface area for a superior microbial population responsible for organic degradation at much low area requirement and capital cost [23]. The interrelationships between the plants and microorganisms associated with biofilms attached to the racks, stems, roots, and water column form a high rate wetland system. A further study also revealed the efficiency of this method planted with Thalia dealbata, Acorus calamus, Zizania latifolia and Iris sibirica for river water treatment [24,25]. Marchand et al. [26] successfully applied a Bio-racks filled with a homogeneous mix of gravels and perlite for the removal of copper ion from synthetic $\mathrm{Cu}$-contaminated wastewaters using Phragmites australis, Juncus articulatus and Phalaris arundinacea.

Hence, it is recommended that using Bio-rack wetland upgraded with ABR should be considered as a novel scientific advancement and integrated approach. This innovation has not been documented before; its performance would be controversial and requires to be optimized thoroughly. This study is aimed to develop and examine the performance of an integrated process of ABR and BRS for effective treatment of domestic wastewater which could be implemented in decentralization practices. The potential ability of two aquatic plants, included Phragmites sp. and Typha sp., in wetland phytoremediation were also compared to find the most efficient and well matched vegetation in the combined $\mathrm{ABR}$ and BRS. This is important to have a comparative assessment on the use of aquatic weeds in the phytoremediation systems, where the most suitable macrophytes are available.

\section{Materials and methods}

\section{The characteristic of wastewater}

The overall characteristic of domestic wastewater during the study period was as follows: $\mathrm{pH} 7.44 \pm 0.12$, total chemical oxygen demand (COD) $751 \pm 43 \mathrm{mg} / \mathrm{L}$, soluble chemical oxygen demand (SCOD) $500 \pm 45 \mathrm{mg} / \mathrm{L}$, biochemical oxygen demand $\left(\mathrm{BOD}_{5}\right) 348 \pm 26 \mathrm{mg} / \mathrm{L}$, dissolved oxygen (DO) $0.19 \pm 0.07 \mathrm{mg} / \mathrm{L}$, total suspended solids (TSS) $528 \pm 41 \mathrm{mg} / \mathrm{L}$, total nitrogen (TN) $64.65 \pm$ $5.14 \mathrm{mg} / \mathrm{L}$, phosphate $\left(\mathrm{PO}_{4}-\mathrm{P}\right) 13.7 \pm 1 \mathrm{mg} / \mathrm{L}$, total coliform $5.27 \times 10^{7} \pm 1.8 \times 10^{7} \mathrm{MPN} / 100 \mathrm{ml}$, and total viable count (TVC) $3.30 \times 10^{7} \pm 6.53 \times 10^{6} \mathrm{cfu} / \mathrm{ml}$.

\section{Chemicals and instrumentation}

The chemicals used in this study were of analytical grade (from Merck, Germany) as follows: Borax, Bromocresol green (5\%), Citric acid, Ferroin indicator, Formaldehyde solution, Methyl red (1\%), Starch, $\mathrm{Ag}_{2} \mathrm{SO}_{4}, \mathrm{CaCl}_{2}$, $\mathrm{C}_{20} \mathrm{H}_{14} \mathrm{O}_{4}, \mathrm{C}_{2} \mathrm{H}_{5} \mathrm{OH}, \mathrm{CuSO}_{4} \cdot 5 \mathrm{H}_{2} \mathrm{O}, \mathrm{FeCl}_{3} \cdot 6 \mathrm{H}_{2} \mathrm{O}, \mathrm{Fe}\left(\mathrm{NH}_{4}\right)_{2}$ $\left(\mathrm{SO}_{4}\right)_{2} .6 \mathrm{H}_{2} \mathrm{O}, \mathrm{H}_{3} \mathrm{BO}_{3}, \mathrm{HCl}, \mathrm{HgSO}_{4}, \mathrm{H}_{2} \mathrm{SO}_{4}, \mathrm{~K}_{2} \mathrm{Cr}_{2} \mathrm{O}_{7}, \mathrm{KI}$, $\mathrm{KH}_{2} \mathrm{PO}_{4}, \mathrm{~K}_{2} \mathrm{HPO}_{4}, \mathrm{~K}_{2} \mathrm{SO}_{4}, \mathrm{MnSO}_{4} .4 \mathrm{H}_{2} \mathrm{O}, \mathrm{NaCl}, \mathrm{NaHCO}_{3}$, $\mathrm{NaN}_{3}, \mathrm{NaOH}, \mathrm{Na}_{2} \mathrm{SO}_{4}, \mathrm{Na}_{2} \mathrm{~S}_{2} \mathrm{O}_{3} .5 \mathrm{H}_{2} \mathrm{O}, \mathrm{Na}_{2} \mathrm{HPO}_{4} .7 \mathrm{H}_{2} \mathrm{O}$, $\mathrm{Na}_{2} \mathrm{~S}_{2} \mathrm{O}_{3} .5 \mathrm{H}_{2} \mathrm{O},\left(\mathrm{NH}_{4}\right)_{6} \mathrm{Mo}_{7} \mathrm{O}_{24} .4 \mathrm{H}_{2} \mathrm{O},\left(\mathrm{NH}_{4}\right)_{2} \mathrm{~S}_{2} \mathrm{O}_{8}, \mathrm{NH}_{4} \mathrm{Cl}$, $\mathrm{MgSO}_{4} \cdot 7 \mathrm{H}_{2} \mathrm{O}$, Nutrient agar, and MacConkey broth.

The sample $\mathrm{pH}$ was measured by a $\mathrm{pH}$-meter model 75P (Istek, Korea). COD tests were performed by using the open-reflux digestor model EME6/CEB (Electrothermal, UK). TN was examined via the semimicro Kjeldahl setup. UV-visible spectrophotometer model P/N BUV40X00 
(PerkinElmer, USA) was used to measure $\mathrm{PO}_{4}-\mathrm{P}$. Steroscan 440 scanning electron microscope (SEM, Leica, Cambridge, UK) was used during observation of active biomass on the support matrix (Bio-rack).

\section{Pilot plant setup}

Two bench scale anaerobic baffled reactors (ABR) in parallel followed by horizontal flow Bio-rack system (BRS) vegetated with Phragmites sp. and Typha sp. were set-up on the premises of Water and Wastewater Research Centre (WWRC), Water Research Institute (WRI), Tehran, Iran. The pilot plants were comprised of three major sections including storage tanks (70 L), constant head tanks (20 L), and wetland units (Figure 1).

Each Plexiglas anaerobic baffled reactor (Length: $0.94 \mathrm{~m}$, Width: $0.16 \mathrm{~m}$, Height: $0.5 \mathrm{~m}$ ) with $60 \mathrm{~L}$ net volume, consists of equally six compartments. The compartments were arranged by further vertical baffles dividing upflow-to-downflow parts by a ratio of $3: 1$ to affect the fluid dynamics in the sludge bed [7]. In this process, the wastewater force to flow under and over the baffles from one compartment to the next as it passes from the inlet to the outlet. The biogas formed during the anaerobic fermentation was released by the exhaust valves located on the top of the reactor.

The wetland systems (Bio-rack units) included a rectangular tank measuring $0.32 \mathrm{~m} \times 0.3 \mathrm{~m} \times 0.6 \mathrm{~m}(\mathrm{~L} \times$ $\mathrm{W} \times \mathrm{H}$ ), an effective depth of $0.54 \mathrm{~m}$, and a $50 \mathrm{~L}$ void volume in the presence of vegetation and other internals. Unique feature of this system is the presence of 15 vertical PVC pipes (a $500 \mathrm{~mm}$ effective height $\times 60 \mathrm{~mm}$ outer diameter), free of soil strata, assembled as a rack and called Bio-rack. The pipes contained numerous surface perforations (20 mm diameter) for liquid transportation. These Bio-racks are involved in the treatment process by holding vegetation and providing an abundant attachment site for microbial growth. In this practice, the wastewater is distributed uniformly and then flows horizontally through the support matrix (Bio-racks), stems and roots of the plants to treat by physical and biological processes. The occupied area and specific surface of the matrix Bio-rack were $0.06 \mathrm{~m}^{2}$ and $55 \mathrm{~m}^{2} / \mathrm{m}^{3}$ effective volume (57 $\mathrm{m}^{2} / \mathrm{m}^{3}$ filled volume), respectively. Sixty Phragmites sp. and thirty Typha sp. plants were held in the support matrix of the Bio-rack at the initial stage of the plantation. The lower number of Typha sp. was used because these plans are larger in size compared to Phragmites sp. The inlet and outlet arrangements were made as per standard practices.

\section{Start-up and acclimatization}

The experiments were initiated with the batch mode of merely anaerobic baffled reactors by seeding the mixture of cow dung and sewage sludge at the ratio of 1:2 (50\% $\mathrm{v} / \mathrm{V}$ ) on effluent wastewater in each compartment for 2 weeks. The content of the reactors was recycled for homogeneity in the same period. Subsequently, the two comparable anaerobic baffled reactors in combination with Bio-rack systems were operated through serial exposure of sewage starting from $25 \%$ loading rate, which was increased gradually to $100 \%$ at an overall HRT of 44 hours over a 25 day period. In this stage, the systems continued to perform for more 45 days until the reduction in the percentage of COD reached a constant level, which was considered as the acclimatization period. Initially, the plant density was low and gradually the plant growth and reached their maximum possible number as bacterial growth was enhanced. In that order, the ratio of the volatile fatty acids to total alkalinity concentration was observed to be maintained below 0.3 at the outlet end of the ABR during studies.

It is noteworthy to say that the Phragmites sp. and Typha sp. were obtained from marshy lands of Tehran Province and Malayer County, respectively. Sampling was accomplished with simple hand tools. The underground parts (roots and bulbs) of the plants were carefully dug up, and the soil removed with care. A plastic collection container containing water marsh was used for transferring the sampled plants and minimizing their damage through several mechanisms. In the lab, the

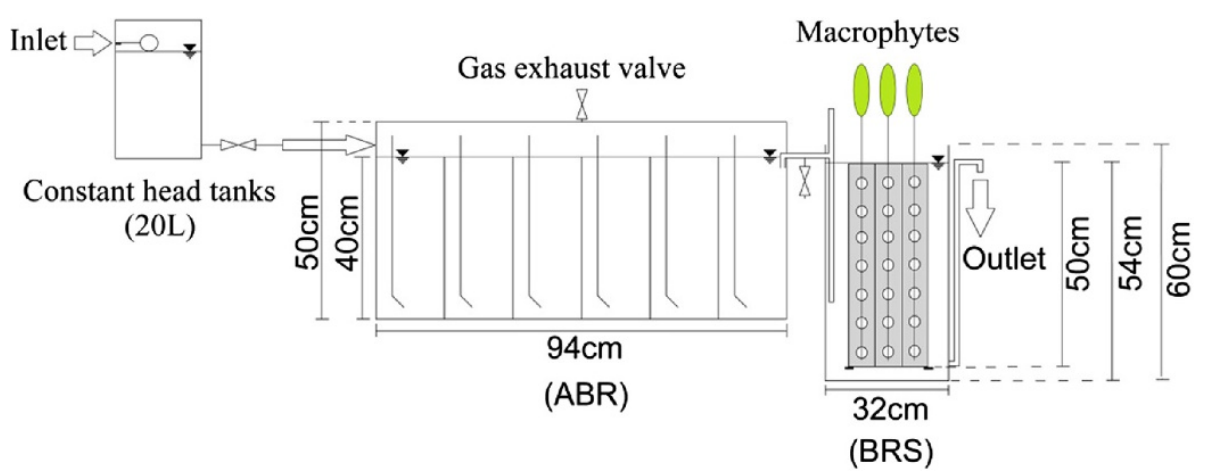

Figure 1 Schematic diagram of the integrated treatment systems (ABR: anaerobic baffled reactor (ABR), BRS: bio-rack system). 
roots of sampled plants were washed with tap water to remove any remaining adsorbed soil particles before preliminary plantation. The type of the plants determined with the help of the National Botanical Garden, Teharan, Iran.

\section{Operational procedure}

The integrated systems of ABR and Bio-rack wetland vegetated with Phragmites sp. and Typha sp. were operated in an ambient air temperature $\left(25-29^{\circ} \mathrm{C}\right)$, where sunlight could effectively penetrate. Temperatures were not controlled except to prevent the effect of cold weather. After the acclimatization period, the experiments were initiated during February 2012 to 2013 to determine the state of present processes denoted by hydraulic retention time (HRT), treatment performance and plant growth with the intention of organic pollutant elimination considering the effluent discharge norms specified by the national pollution control board of Iran (COD $<100 \mathrm{mg} / \mathrm{L}$, and $\mathrm{BOD}_{5}<30 \mathrm{mg} / \mathrm{L}$ ), that is required for discharge into natural water resources. Under steady state condition, the systems were operated in six phases (Table 1). The daily flow was calculated by taking into account the theoretical HRT of ABR, and subsequently examined the HRT of wetland unit through each phase. The theoretical HRT, $t$ (hours), of each treatment unit was established from the following equation:

$$
\mathrm{t}=\frac{\mathrm{V}}{\mathrm{Q}}
$$

where $\mathrm{V}(\mathrm{L})$ is the void volume of the reactor, and $\mathrm{Q}$ (L/hour) is the design flow rate. Wastewater flow (L/day) expresses the design wastewater flow over a 24 hour period. Overall HRT indicates the sum of retention time both ABR and wetland system.

The inflow rates were fixed accordingly to $65,80,96$, 114, 126 and 144 L/day for overall HRTs of 41, 33, 27,
23, 21 and 18 hours, respectively. The systems are operated at each retention time for 60 days, during which the effluent characteristics with an almost constant percentage reduction were achieved.

Additionally, the old plants were removed periodically and new plants were retained or allowed to grow during experimentations. In general, the roots of young plants can display greater ability to absorb impurities and release oxygen than old plants due to the age of the plants and tissues. Therefore, it is important to use healthy young plants for the more efficient contaminant removal [27]. Sodium bicarbonate is a buffer used to stabilize $\mathrm{pH}$ as per requirement in $\mathrm{ABR}$.

\section{Wastewater sampling and analysis}

Raw wastewater samples were collected from a residential source of WWRC, WRI, Iran, on a daily basis for performance evaluation. The samples from the inlet and outlet of the reactors was analyzed every $24 \mathrm{~h}$ at $10 \mathrm{am}$ for $\mathrm{pH}, \mathrm{COD}, \mathrm{SCOD}, \mathrm{BOD}_{5}, \mathrm{TSS}, \mathrm{TN}, \mathrm{PO}_{4}-\mathrm{P}$ and MPN of coliform bacteria according to the standard method [28]. In that order, the samples were merely filtered through Whatmann 42 before testing of SCOD and $\mathrm{BOD}_{5}$. The microbial population presented in the inlet and outlet, plant root surface, and Bio-rack surface were examined to determine the total viable count (TVC) using the pour plate technique [28]. The active attached biomass on the surface of Bio-racks was observed by using scanning electron microscope (SEM) as per the standard procedure [29]. Bacteria presented on the support matrix (Bio-racks) were merely isolated on nutrient agar medium and the Gram-negative bacterial identification was done using Mini API (BioMérieux, France).

\section{Botanical aspects}

The morphological characteristics of Phragmatis sp. and Typha sp. in terms of the number of leaves, size of the

Table 1 Experimental conditions implied in wastewater treatment

\begin{tabular}{|c|c|c|c|c|c|c|}
\hline $\begin{array}{l}\text { Phase } \\
\text { Item }\end{array}$ & I & II & III & IV & V & VI \\
\hline Operation period (day) & 60 & 60 & 60 & 60 & 60 & 60 \\
\hline Overall HRT (hours) & 41 & 33 & 27 & 24 & 21 & 18 \\
\hline $\mathrm{HRT}_{\mathrm{ABR}}$ (hours) & 22 & 18 & 15 & 13 & 11 & 10 \\
\hline $\mathrm{HRT}_{\mathrm{BRS}}$ (hours) & 19 & 15 & 12 & 11 & 9 & 8 \\
\hline Q (L/day) & 65 & 80 & 96 & 114 & 126 & 144 \\
\hline \multicolumn{7}{|l|}{ OLR } \\
\hline (g COD/day) & $50 \pm 2.63$ & $61 \pm 3.02$ & $68 \pm 2.02$ & $85 \pm 6.02$ & $93 \pm 6.46$ & $113 \pm 2.56$ \\
\hline (g BOD $5 /$ day) & $23 \pm 1.96$ & $29 \pm 2.60$ & $33 \pm 2.09$ & $40 \pm 3.51$ & $43 \pm 3.07$ & $50 \pm 4.11$ \\
\hline$\left(\mathrm{g} \mathrm{COD} / \mathrm{m}^{3} / \text { day }\right)^{*}$ & $455 \pm 24$ & $553 \pm 27$ & $622 \pm 18$ & $769 \pm 55$ & $843 \pm 59$ & $1024 \pm 23$ \\
\hline$\left(\mathrm{g} \mathrm{BOD}_{5} / \mathrm{m}^{3} / \text { day }\right)^{*}$ & $205 \pm 18$ & $260 \pm 24$ & $302 \pm 19$ & $361 \pm 32$ & $392 \pm 28$ & $452 \pm 37$ \\
\hline
\end{tabular}

HRT: hydraulic retention time; Q: flow rate; OLR: organic loading rate ${ }^{*}$ based on the sum of effective volume both ABR and BRS. 
leaves, number of roots, longest root, dry weight, and ash weight were analyzed every 15 days over a 3 month period throughout the six phases of the HRT evaluation to monitor morphological changes in the plants as per standard practice [30].

\section{Statistical analysis}

The data of 365 consecutive days were analyzed to examine the performance of two integrated systems. Treatment efficiency was calculated as the percentage of removal for each parameter as follows:

$$
\text { Removal efficiency }(\%)=\frac{\mathrm{Ci}-\mathrm{Ce}}{\mathrm{Ci}} \times 100
$$

where $C_{i}$ and $C_{e}$ are the influent and effluent concentrations. Organic loading rates, OLR (g/day), were calculated by multiplying the discharge flow (L/day) and the organic concentrations $(\mathrm{g} / \mathrm{L})$. Relative growth rate of the plants is calculated using the following equation:

$$
\text { Relative growth rate }(\%)=\frac{\ln \mathrm{W} 2-\ln \mathrm{W} 1}{\mathrm{t} 2-\mathrm{t} 1} \times 100
$$

where $W_{1}$ and $W_{2}$ are the dry weight of plants at times $t_{1}$ and $t_{2}$. Statistical analysis of the data to compare integrated systems on the organic load removal and morphological characteristics of plants growth were done through the variance (ANOVA) and Duncan test using SPSS software [31]. Performance differences were deemed to be significant if $\mathrm{p}<0.05$.

\section{Results and discussions}

This investigation discusses the possibility application of the Bio-rack wetland system as a post-treatment of anaerobic baffled reactor through single specimens of Phragmites $s p$. or Typha sp. for DEWATS. In the previous study, the performance of ABR throughout eight-compartment treating domestic wastewater was assessed, simulated, and optimum configuration was determined $[9,10]$. The ABR toward the treatment of domestic wastewater $(750 \mathrm{mg}$ COD/L) clearly showed a stable performance under different hydraulic retention times by having a high compartments number (more than 5). Therefore, the six-compartment ABR was selected in the present study to ensure an effective pre-treatment condition in treating domestic wastewater.

\section{Organic pollutant removal}

Since, the constancy of any biological process thoroughly depends on the hydraulic and organic loading rates; the experiments were performed to estimate the satisfactory hydraulic retention time (HRT) of the whole integrated process of ABR followed by Bio-rack system using Phragmites sp. (ABR-BRSUP) and Typha sp. (ABR-BRSUT).

The SCOD and $\mathrm{BOD}_{5}$ concentration of the treated effluent was below 60 and $30 \mathrm{mg} / \mathrm{L}$ at overall HRTs above 21 and 27 hours, in the treatment systems planted by Phragmites sp. and Typha sp., respectively (Figure 2). Likewise, the COD concentration was exceeded Irans's permissible limit at below 21 (95 $\mathrm{mg}$ COD/L) and 27 (97 mg COD/L) hours HRTs. An ANOVA and Duncan test done on the performance data in terms of $\mathrm{BOD}_{5}$ removal indicate that the differences exist between the performances of these two processes; p-value was less than 0.05 merely at overall HRT of 21 and 18 hours (Table 2). The supremacy of the Bio-rack wetland vegetated with Phragmites sp. would be significant in lower retention times. Therefore, overall HRTs of 21 and 27 hours are considered to achieve a satisfactory organic removal performance in ABR-BRSUP and ABR-BRSUT, respectively.

Many studies comparing planted systems over unplanted units have been conflicting results regarding the importance of plants in any phytoremediation process $[32,33]$. In the absence of the rhizomes of the plants, the micro-sites occupied by the wetland unit become anaerobic; lead to a lower rate of impurities elimination. The major advantage associated with the current integrated treatment systems is the presence of the Bio-rack wetland. The Bio-rack process planted with Phragmites sp and Typha sp. examined to offer, respectively, a lower HRT of 9.5 (COD: 77\%, SCOD: 79\%, BOD 5 : 84\% reduction) and 12.5 (COD: 66\%, SCOD: 69\%, BOD $_{5}: 76 \%$ reduction) hours in polishing anaerobic effluent as compared to other relevant literatures $[2,14,15]$. Kaseva [14] reported average COD removal efficiencies of $56 \& 61 \%$ at HRT of 1.96 and 1.99 days in the conventional constructed wetlands using Phragmites sp. and Typha sp., respectively. Mbuligwe [15] was determined the efficiency of conventional constructed wetlands using Typha sp. and Colocasia sp., respectively, by $79 \& 75 \%$ COD reduction at 1.2 days HRT. The Biorack wetland used in this study also showed a higher removal of organic pollutant compared to the duckweed system, in which 54 \& 58\% COD, 63 \& 64\% SCOD and 21 \& $63 \% \mathrm{BOD}_{5}$ reduction could be accomplished at 10 and 15 days HRT, respectively [2]. It can be verified that wetland type, efficient oxygen diffusion, and the high accumulation of the attached bacterial populations on the surface of support matrix are the major factors for high level of removal efficiency in the Bio-rack process.

The Bio-rack wetland with Phragmites sp. exhibits a higher rate of pollutant reduction owing to the extensive root system of the plant which is responsible for desirable rate of the oxygen transfer efficiency, and greater microbial mass contribution in the treatment unit. However, there was a little difference in the removal of organic pollutant at longer retention times during the operation of 
(a)

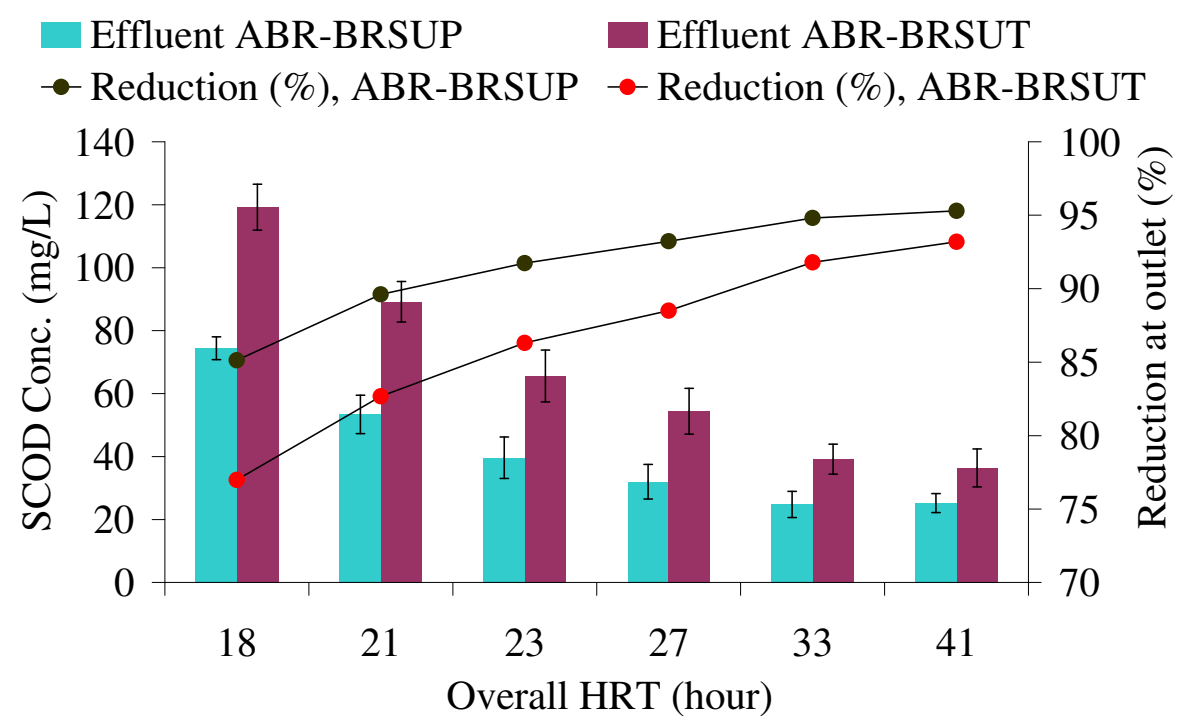

(b)

$\begin{array}{ll}\text { Effluent ABR-BRSUP } & \text { Effluent ABR-BRSUT } \\ \bullet-\text { Reduction }(\%), \text { ABR-BRSUP } & \bullet-\text { Reduction (\%), ABR-BRSUT }\end{array}$

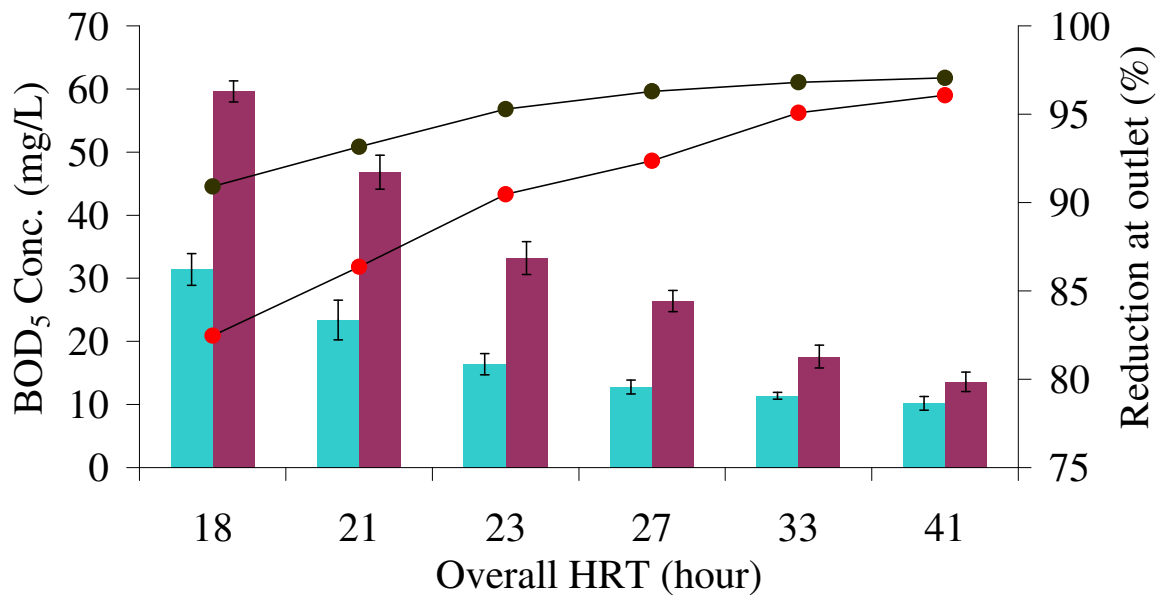

Figure 2 Effluent (a) SCOD and (b) $\mathrm{BOD}_{5}$ concentrations with five days repetition through the integrated systems.

both treatment processes. The visual observation showed that the Phragmites sp. tends to develop a wonderfully root system which occupies thoroughly over the depth of the treatment unit. Typha sp. appears to have a shallower root system.

\section{Dissolve oxygen silhouette in the reactor}

Adequate dissolved oxygen required for bacterial oxidation is relatively inefficient by a transfer process of atmospheric diffusion, and in the Bio-rack wetland the transfer is likely to be smaller since the dense plant cover reduces surface gas-exchange. Vegetation plays a significant role in transferring oxygen via aerenchyma
Table 2 Organic pollutant removal with five days repetition through the integrated systems

\begin{tabular}{llll}
\hline $\begin{array}{l}\text { Overall } \\
\text { HRT (hour) }\end{array}$ & $\begin{array}{l}\mathrm{BOD}_{5} \text { removed-g/day } \\
(\text { ABR-BRSUP) }\end{array}$ & $\begin{array}{l}\mathrm{BOD}_{5} \text { removed-g/day } \\
\text { (ABR-BRSUT) }\end{array}$ & P-Value \\
\hline 41 & $21.85 \pm 1.96$ & $21.63 \pm 1.90$ & 0.486 \\
33 & $27.71 \pm 2.60$ & $27.21 \pm 2.50$ & 0.398 \\
27 & $31.95 \pm 2.2$ & $30.64 \pm 2.23$ & 0.102 \\
23 & $37.85 \pm 3.60$ & $35.93 \pm 3.56$ & 0.062 \\
21 & $40.14 \pm 2.93$ & $37.19 \pm 2.80$ & 0.016 \\
18 & $45.21 \pm 4.20$ & $41.15 \pm 4.25$ & 0.007 \\
\hline
\end{tabular}

HRT: hydraulic retention time;

ABR-BRSUP: anaerobic baffled reactor - bio-rack system using Phragmites sp.; ABR-BRSUT: anaerobic baffled reactor - bio-rack system using Typha sp. 


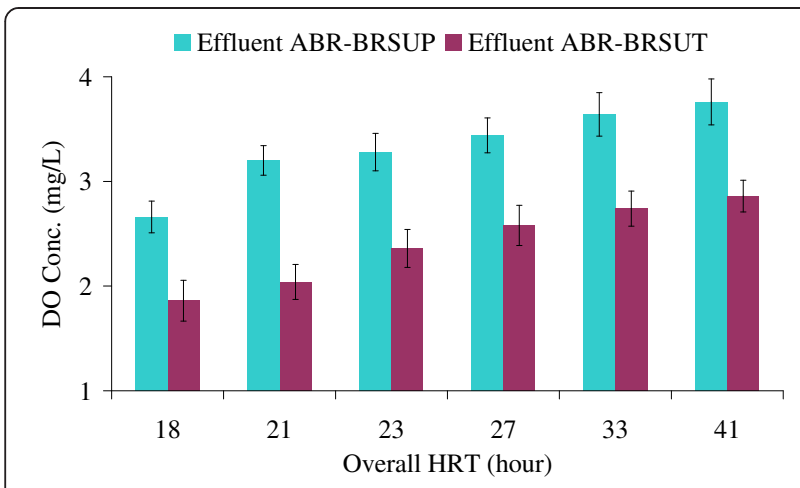

Figure 3 Mean DO values of the processes effluent with five days repetition.

tissue [32]. The dissolved oxygen inside the Bio-rack cells was estimated to be an average of 3.2 and $2.6 \mathrm{mg} / \mathrm{L}$ $\mathrm{O}_{2}$ at overall HRTs of 21 and $27 \mathrm{~h}$ in ABR-BRSUP and ABR-BRSUT, respectively (Figure 3). The results suggest that the mechanism of aerobic respiration is a key microbial population in the Bio-rack process due to high rate of oxygen transfer efficiency through the roots. The aerobic bacteria are fast growing microflora causing a greater rate of organic elimination compared to anaerobic microorganism. The higher level of dissolved oxygen in the Bio-rack unit planted with Phragmites sp. probably can be explained by type of plant having an extensive root system; allows oxygenation to occur from the roots through the entire depth of the treatment unit.

\section{Treatment performance}

A comprehensive evaluation of other parameters was conducted at reasonable overall HRTs of 21 and $27 \mathrm{~h}$ (Table 3). Regarding to the results, it can be concluded that high organic loads of $\mathrm{BOD}_{5}$ and TSS of influent can be efficiently alleviated in ABR as a pretreatment of the Bio-rack wetlands. The data evaluated in the previously reported literature, likewise, specified a possible need of a longer retention period in the Bio-rack wetlands if they use as a standalone method in treating domestic wastewater with high organic pollutant concentrations (COD > $440 \mathrm{mg} / \mathrm{L}, \mathrm{BOD}_{5}>238 \mathrm{mg} / \mathrm{L}$ ), whenever plants respond positively [21]. Therefore, the appropriateness of the ABR process for primary sanitation can be remarkable to improve the performance of the phytoremediation systems; meanwhile it can also decrease choking and clogging problems associated with quality variations of the influent in the conventional wetland processes. This can be implied by standard deviations shown in Table 3 .

Both integrated systems can also be a viable option to reduce nutrient levels by more than $75 \% \mathrm{TN}$ and $14 \%$ $\mathrm{PO}_{4}$-P. Dissolved oxygen concentration would seem to be more than $2.5 \mathrm{mg} / \mathrm{L}$ in the wetland units. Phragmites sp. has a great potential distribution of roots enhanced nutrient uptake by the root segments in their favorable environment. Literature based evaluation confirms that the present processes potentially have a higher nutrient reduction of $40-58 \%$ TN compared to the anaerobic baffled reactor as a standalone solution [2]. It would emphasize that the application of the Bio-rack wetlands, as a post treatment of ABR can effectively improve the quality of treated domestic wastewater to be discharged to surface waters in rural areas.

The suspended solids are removed throughout the integrated systems via sedimentation and filtration phenomena. The efficiency of nutrient $(\mathrm{N}, \mathrm{P})$ removal can be explained adequately by the nitrification/denitrification of rhizoremediation process and plant uptake route. Nitrogen removal is rather high for both integrated systems. Phosphorus removal is notoriously poor in any constructed wetland practices [32]. The anaerobic systems typically increase the soluble amount of phosphate while can hardly be removed efficiently through the phytoremediation techniques. The greater percentage reduction of phosphorus can be attained by incorporating the advantages of using chemical divalent cations as a result

Table 3 Summary of effluents characteristic with five days repetition from two integrated treatment systems

\begin{tabular}{|c|c|c|c|c|c|c|c|c|}
\hline \multirow[t]{2}{*}{ Parameters* } & \multicolumn{4}{|c|}{ ABR-BRSUP (overall HRT of 21 hours) } & \multicolumn{4}{|c|}{ ABR-BRSUT (overall HRT of 27 hours) } \\
\hline & Inlet & Outlet at ABR & Outlet at BRSUP & $\begin{array}{l}\text { Overall } \\
\text { reduction (\%) }\end{array}$ & Inlet & Outlet at ABR & Outlet at BRSUT & $\begin{array}{l}\text { Overall } \\
\text { reduction (\%) }\end{array}$ \\
\hline $\mathrm{pH}$ & $7.45 \pm 0.09$ & $7.10 \pm 0.05$ & $7.19 \pm 0.04$ & - & $7.50 \pm 0.10$ & $7.15 \pm 0.06$ & $7.29 \pm 0.05$ & - \\
\hline DO & $0.16 \pm 0.05$ & - & $3.2 \pm 0.14$ & - & $0.18 \pm 0.06$ & - & $2.6 \pm 0.20$ & - \\
\hline COD & $736 \pm 51.28$ & $420.4 \pm 30.96$ & $95.2 \pm 2.28$ & 87.1 & $713 \pm 21.40$ & $290 \pm 17.04$ & $97.4 \pm 1.52$ & 86.3 \\
\hline SCOD & $515 \pm 42.51$ & $256 \pm 25.26$ & $53.4 \pm 6.12$ & 89.6 & $473 \pm 24$ & $173.8 \pm 26.25$ & $54.4 \pm 7.85$ & 88.5 \\
\hline $\mathrm{BOD}_{5}$ & $342 \pm 24.36$ & $150 \pm 12.32$ & $23.4 \pm 3.13$ & 93.2 & $345.6 \pm 22$ & $110 \pm 8.12$ & $26.4 \pm 1.67$ & 92.4 \\
\hline TSS & $523.4 \pm 48.22$ & $245 \pm 42.66$ & $61 \pm 11.71$ & 88.3 & $521 \pm 47$ & $237.2 \pm 28.62$ & $71.2 \pm 7.33$ & 86.3 \\
\hline TN & $67.97 \pm 3.88$ & $56.31 \pm 5.17$ & $14.02 \pm 0.64$ & 79.4 & $63.45 \pm 5.72$ & $51.25 \pm 4.61$ & $14.41 \pm 0.32$ & 77.3 \\
\hline $\mathrm{PO}_{4}-\mathrm{P}$ & $13.65 \pm 0.65$ & $20.26 \pm 1.82$ & $10.73 \pm 1.16$ & 21.4 & $15.30 \pm 0.43$ & $22.69 \pm 2.25$ & $13.13 \pm 1.04$ & 14.2 \\
\hline
\end{tabular}

*All analytical values except $\mathrm{pH}$ are based on $\mathrm{mg} / \mathrm{L}$. 
of superior exchange reaction mechanism. Furthermore, the nutrient elimination would be succeeded by frequent harvesting of plants based on climate condition.

\section{Microbial investigation}

The MPN of total coliform and TVC concentrations at the outlet of two integrated processes at overall HRTs of 21 and $27 \mathrm{~h}$ are shown in Figure 4. The average reduction of these parameters was observed approximately 99\% at the outlet end of the processes. In wetland units, there is a reduction of the TVC level at the outlet, and biological mass is getting attached to the surface of the
Bio-racks. This could be phenomena in the initial stage of operation. At steady state condition, there will be uniform growth on the Bio-rack surfaces, and biomass will slough and come out with the flowing water.

The microorganisms create a sort of natural polymer responsible for their adhesion to develop the biofilm and biooxidation mechanism [34]. The support matrix (Bio-rack) provides the evidence of enormous TVC concentrations (Figure $4 \mathrm{~b}$ ). TVC concentrations were also found to be high both on the root surface of Phragmites sp. and Typha sp. It should be realized that Phragmites sp. with its extensive root system enhanced bacterial population throughout

(a)

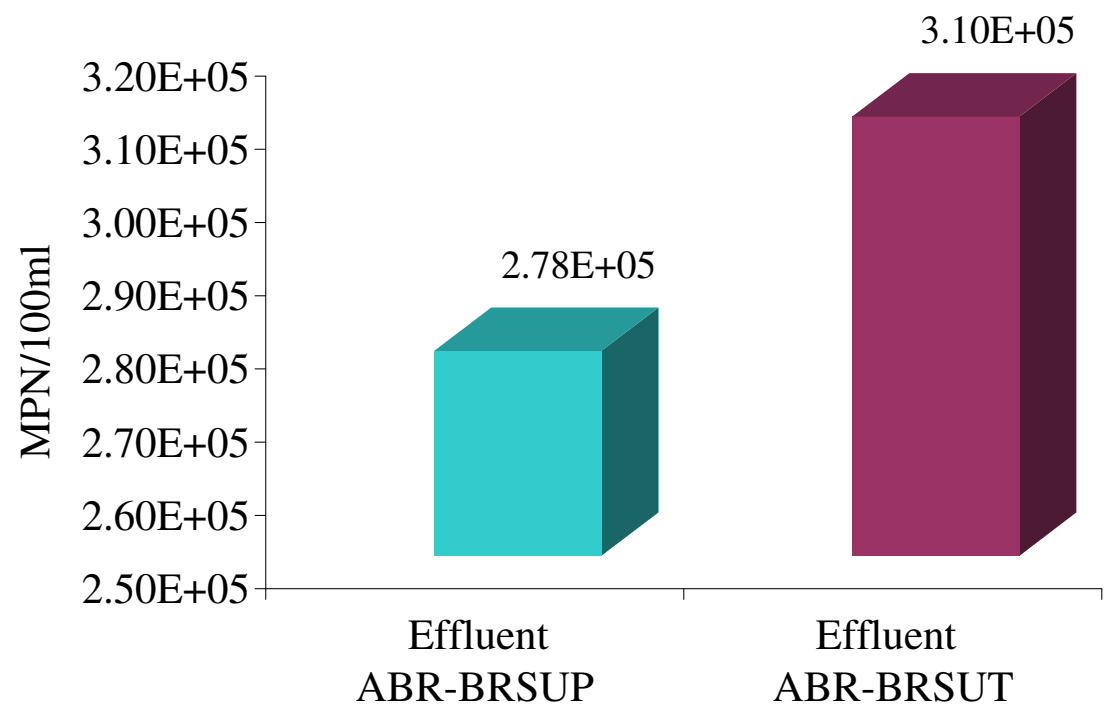

(b)

ABR-BRSUP $\square$ ABR-BRSUT

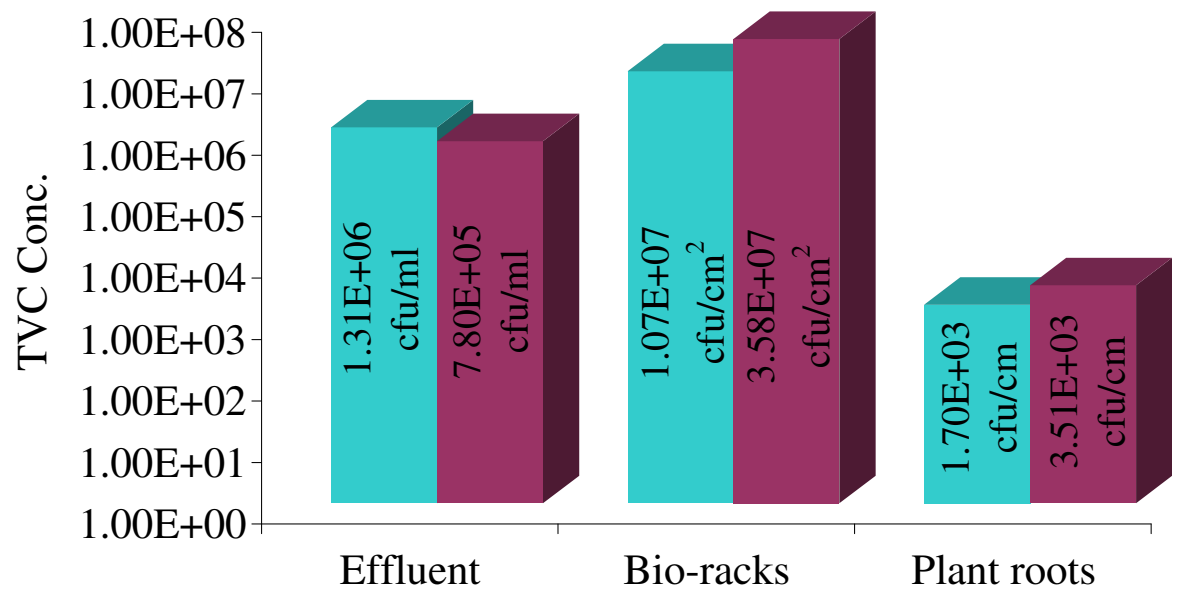

Figure 4 Mean (a) total coliform and (b) total viable count values through the integrated systems. 
the Bio-rack unit. In the Bio-rack wetland, the vicinity of the support matrix, stems and roots of the plants are a preferred environment for many micro-organisms to attach and to degrade pollutants in the phytoremediation process.

The biofilm adhesion in the context of bacterial formation was visualized by scanning electron microscope (SEM). The microscopic examinations revealed the bulk of the biomass concentration on the Bio-rack surface media in both ABR-BRSUP and ABR-BRSUT (Figure 5). The biofilm, which were grown on the surface of the Bio-racks, promote somewhat a denser morphology in ABR-BRSUP (overall HRT of 21 hours) compared to ABR-BRSUT (overall HRT of 27 hours). This can be demonstrated by a high flow condition at a low retention

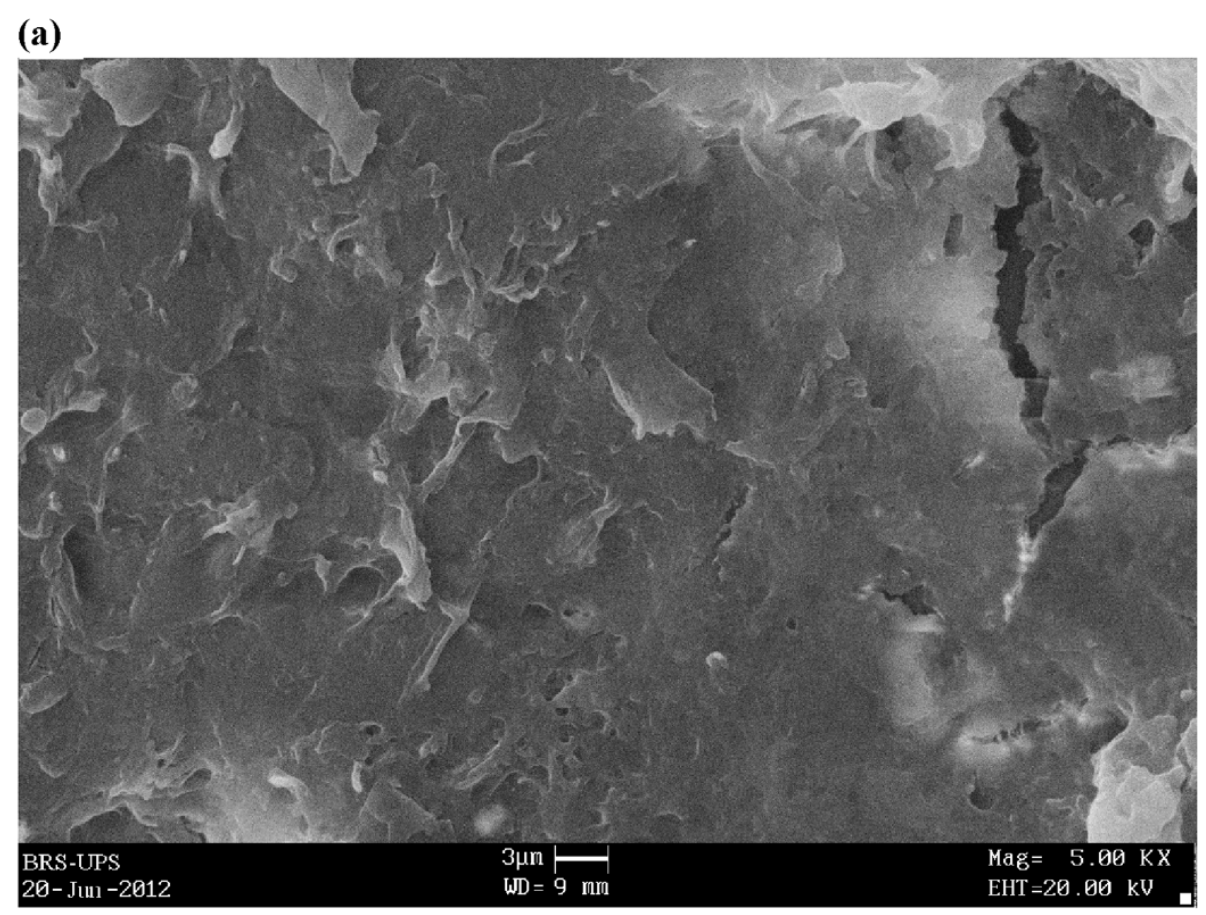

(b)

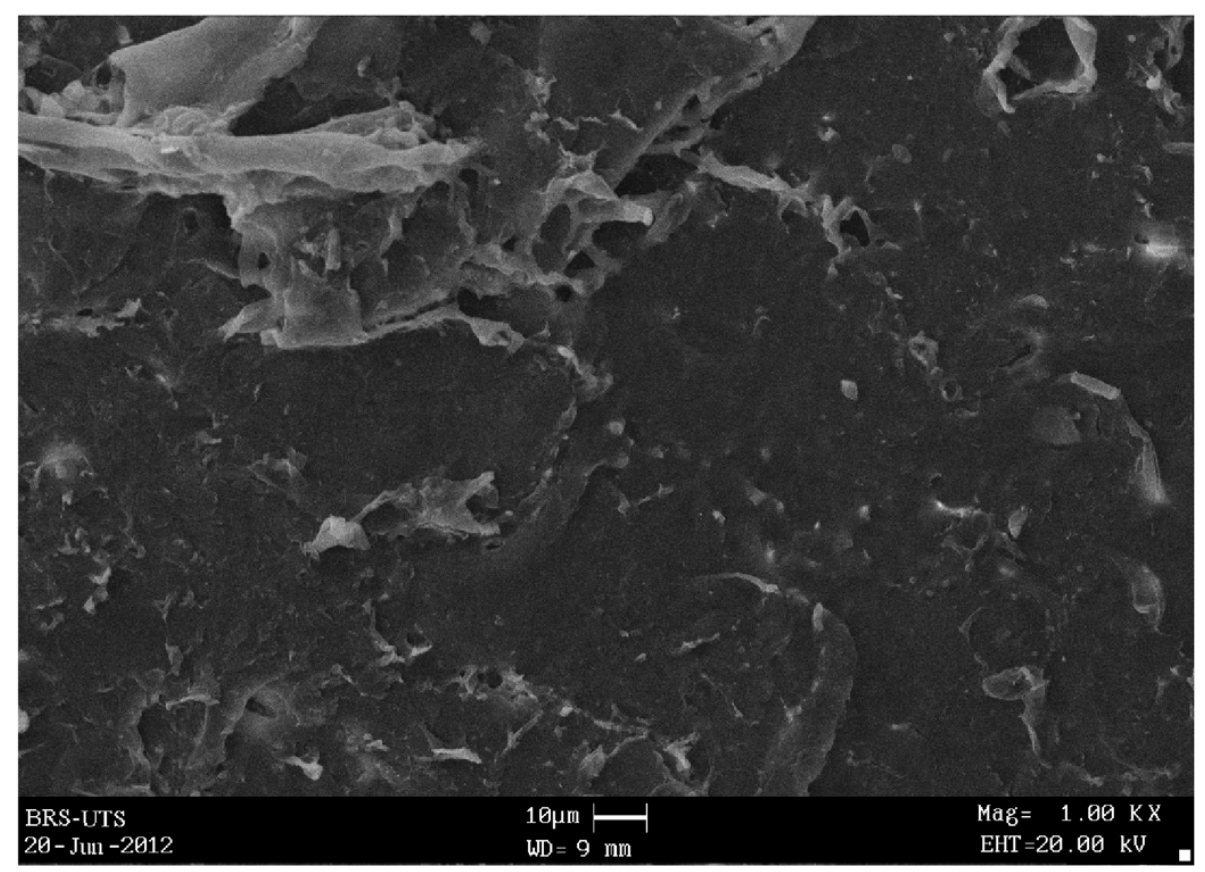

Figure 5 SEM photographs of the biofilm-forming bacteria on the surface of Bio-racks in (a) ABR-BRSUP and (b) ABR-BRSUT. 
time where the viscoelastic nature of extracellular biopolymers holding the microcolonies together. In ABRBRSUT, the morphology of biofilm grown at a low flow discharge exhibit a nearly lower dense and microcolonies are tapered. The high flow condition can also result in the detachment of biofilm, reduce the biofilm bacteria quantity, and increase of effluent bacteria population as a result of a sloughing process. This can be evident from the results on TVC (Figure 4b). Similar phenomena were also reported in the relevant literature [35]. The amount of biofilm formed on the surface of the Bio-rack was estimated to be 7 to 8 and 8 to $9 \mathrm{~g} / \mathrm{L}$ in BRSUP and BRSUT, respectively.

Correspondingly, the profiling of microflora population on the surface of Bio-racks can show the presence of approximately 12 bacterial strains grown on nutrient agar medium i.e. Acinetobacter lwoffii, Aeromonas sobria, Escherichia coli, Pseudomonas stutzeri, Aeromonas hydrophila, Citrobacter koseri, Acienetobacter johnsonni, Entrobacter intermedius, Alcaligenes faecalis, Pantoea sp., Pseudomonas putida, Acinetobacter baumanni; this could verify the results of previous work [21]. It should be noted that there is a possibility of other microbial population, which could not be detected in a nutrient agar medium.

\section{Plant morphological study}

A study of the morphological aspects of the vegetation clearly indicated that anaerobically treated domestic sewage had no detrimental effect on the plant morphology, and the yield of the plants was increased (Table 4). In this study, anaerobically treated effluents were enriched with nutrients, particularly nitrogen (Table 3 ). The absorption and assimilation of nutrients by plants and the natural $\mathrm{pH}$ of the treated effluents may be the reasons for positive influence on the plant growth. Relative growth rate of plants also showed that Phragmites sp. would be more resilient to grow (3.92\%) in the pretreated anaerobic effluent than Typha sp. (0.90\%). The statistical analysis also indicated that there is a significant difference between plants in their growth $(\mathrm{p}<0.05)$, except the longest root which found not significantly different $(\mathrm{p}>0.05)$. These findings suggest that the Phragmites sp. which has a higher mass growth rate can contribute most to phytoremediation process for pollutant removal within a wetland unit (Table 3). The wetland macrophytes can adapt morphologically to grow in a water-saturated substrate through aerenchyma [36].

\section{Pre-estimation of capital cost}

A pre-estimation of economic analysis has been done for $1 \mathrm{~m}^{3}$ /day of sewage inflow based on the results generated by bench scale trials (Table 5). The result of this analysis suggested that the application of the ABRBRSUP process could lead to $24 \%$ less land space than the ABR-BRSUT; making the phytoremediation process more sustainable for DEWATS. The total capital investment of ABR-BRSUP and ABR-BRSUT for an estimated capacity of $1 \mathrm{~m}^{3} /$ day sewage is \$US 90, and \$US 120, respectively. The purpose of this pre-estimation was merely to verify the advantages within the present integrated treatment systems. However, both processes can provide added benefits of an overall low HRT and high pollutant removal efficiency compared to other reported literatures $[2,14,15]$. The low HRT in the present integrated systems reduces the land space requirement; makes the treatment method more valuable. A detailed cost analysis of these processes needs to be performed in subsequent pilot and field experiments.

It can be summarized that the anaerobic baffled reactor followed by Bio-rack wetland can accomplish high rate organic degradation; however, the application of Phragmites sp. can make the treatment process partially more concise and reliable. Yet, the effluent of this process requires disinfection before discharging into the river. In addition, the effluent can also be soil infiltrated in soak pit, leach fields and mounds or else discharged underground at soil depths.

\section{Conclusions}

The studies highlight the performance of an anaerobic baffled reactor followed by Bio-rack wetland planted with Phragmites sp. and Typha sp. for decentralized treatment of domestic wastewater. These processes are characterized by other integrated treatment practices,

Table 4 Morphology characteristics of the plants at initial step and after 15 days operation $(n=5)$

\begin{tabular}{|c|c|c|c|c|c|}
\hline \multirow[t]{2}{*}{ Parameter } & \multicolumn{2}{|l|}{ BRSUP } & \multicolumn{2}{|l|}{$\underline{\text { BRSUT }}$} & \multirow[t]{2}{*}{ P-Value } \\
\hline & Initial & After 15 days & Initial & After 15 days & \\
\hline Number of leaves & $6.2 \pm 1.8$ & $10.4 \pm 1.14$ & $8.8 \pm 1.3$ & $12 \pm 1.6$ & 0.0393 \\
\hline Size of leaves $\left(\mathrm{mm}^{2}\right)$ & $24.3 \pm 2.75$ & $26.65 \pm 2.17$ & $96.02 \pm 22$ & $140.05 \pm 20$ & 0.0001 \\
\hline Number of roots & $9.8 \pm 1.5$ & $28.2 \pm 5.8$ & $45.4 \pm 17.52$ & $94.6 \pm 18.25$ & 0.0005 \\
\hline Longest root (mm) & $12.7 \pm 1.43$ & $16.42 \pm 1.05$ & $19.34 \pm 4.2$ & $22.64 \pm 5$ & 0.0670 \\
\hline Dry weight (g/plant) & $0.65 \pm 0.5$ & $1.17 \pm 0.6$ & $28.39 \pm 1.7$ & $32.49 \pm 1.3$ & 0.0014 \\
\hline Ash weight (g/plant) & $0.035 \pm 0.006$ & $0.114 \pm 0.05$ & $3.018 \pm 0.42$ & $3.91 \pm 0.2$ & 0.0002 \\
\hline
\end{tabular}




\begin{tabular}{|c|c|c|c|c|}
\hline \multirow[t]{2}{*}{ Item } & \multicolumn{2}{|c|}{ ABR-BRSUP } & \multicolumn{2}{|c|}{ ABR-BRSUT } \\
\hline & ABR & BRSUP & ABR & BRSUT \\
\hline Volume $\left(\mathrm{m}^{3} / \mathrm{m}_{\text {inflow }}^{3}\right)$ & 0.48 & 0.41 & 0.63 & 0.54 \\
\hline \multicolumn{5}{|l|}{ Cost } \\
\hline$U S \$ / m_{\text {inflow }}^{3}$ & 30 & 60 & 40 & 80 \\
\hline US\$ $/ \mathrm{kg} \mathrm{BOD}$ removed & 155 & 480 & 167 & 950 \\
\hline \multicolumn{5}{|l|}{ Total cost } \\
\hline US\$ $/ \mathrm{m}_{\text {inflow }}^{3}$ & 90 & & 120 & \\
\hline US\$ $/ \mathrm{kg} \mathrm{BOD}_{5}$ removed & 635 & & 1117 & \\
\hline
\end{tabular}

ABR: anaerobic baffled reactor; BRSUP: bio-rack system using Phragmites sp.; BRSUT: bio-rack system using Typha sp.

where conventional wetland systems have provided in case further polishing of anaerobic effluent and in lieu, a support matrix (Bio-rack) is provided to enrich the aerobic bacteria in the form of biofilm within wetland unit. They eliminate possible limitations of ABR and Bio-rack wetland as standalone solutions, respectively, relating to low nutrient elimination and high organic load restriction. The integrated system planted with Phragmites sp. has low space requirement, low capital investment, and most importantly, high degradation of organic pollutants, which was capable of achieving COD, SCOD, and $\mathrm{BOD}_{5}$ removal as high as $87 \%, 90 \%$ and $93 \%$, respectively, at an overall HRT of $21 \mathrm{~h}$. The integrated process using Typha sp. also showed stable and consistent performance in degradation of organic pollutants, where it was possible to remove $86 \%$ COD, $89 \%$ SCOD, and $92 \%$ $\mathrm{BOD}_{5}$ at an overall HRT of $27 \mathrm{~h}$. Both of these integrated processes are effective for nitrogen removal (77-79\%) whereas they are less efficient in removing phosphorus (14 - 21\%); divalent cation materials can be incorporated. The relative growth rate could make Phragmites (3.92\%) a good species for phytoremediation activities than Typha sp. $(0.90 \%)$. Phragmites sp. has adapted its root system to extend over the depth of the wetland unit, resulting in higher oxygen transfer efficiency through the roots, better nutrient uptake, and larger surface area for aerobic microbial biofilm to adhere and growth compared to Typha sp. This is a principal function of Phragmites sp. that can potentially increase pollutant reduction in the treatment unit $(\mathrm{p}<0.05)$. It can be concluded that present integrated processes (especially by using Phragmites sp.) can be an ideal technology for DEWATS; however, this calls for detail pilot scale and field studies.

\section{Competing interests}

We certify that there is no conflict of interest with any financial organization regarding the material discussed in this manuscript.

\section{Authors' contributions}

The overall implementation of this study including experimental design, data analysis and manuscript preparation were done by SJ, AA, KW and AV. AV critically reviewed and revised the article. All authors read and approved the final manuscript.

\section{Acknowledgements}

The authors wish to thank to the Water Research Institute (WRI)-Water and Wastewater Research Center (WWRC), Tehran, Iran as well as Yeungnam University of KOREA for their valuable assistance in accomplishing this study.

\section{Author details}

'Department of Environmental Engineering, Faculty of Environment, University of Tehran, Tehran, Iran. ${ }^{2}$ Water Research Institute (WRI), Tehran, Iran. ${ }^{3}$ Department of Civil Engineering, Yeungnam University, Gyungsan, South Korea.

Received: 14 January 2014 Accepted: 15 October 2014

Published online: 25 October 2014

\section{References}

1. Massoud MA, Tarhini A, Nasr JA: Decentralized approaches to wastewater treatment and management: applicability in developing countries. Environ Manage 2009, 90:652-659.

2. Nasr FA, Doma HS, Nassar HF: Treatment of domestic wastewater using an anaerobic baffled reactor followed by a duckweed pond for agricultural purposes. Environmentalist 2009, 29:270-279.

3. Badalians Gholikandi G, Jamshidi S, Valipour A: Application of electrolysis upgrading the operation of anaerobic reactors. Environ Stud 2013, 38:9-16.

4. $Y u Y, L U X, W u Y$ : Performance of an anaerobic baffled filter reactor in the treatment of algae-laden water and the contribution of granular sludge. Water 2014, 6:122-138.

5. Foxon KM, Pillay S, Lalbahadur T, Rodda N, Holder F, Buckley CA: The anaerobic baffled reactor (ABR): an appropriate technology for on-site sanitation. Water SA 2004, 30:44-50.

6. Wang J, Huang $Y$, Zhao X: Performance and characteristics of an anaerobic baffled reactor. Bioresour Technol 2004, 93:205-208.

7. Sarathai $Y$, Koottatep T, Morel A: Hydraulic characteristics of an anaerobic baffled reactor as onsite wastewater treatment system. J Environ Sci 2010, 22:1319-1326.

8. Liu R, Tian Q, Chen J: The developments of anaerobic baffled reactor for wastewater treatment: a review. Afr J Biotechnol 2010, 9:1535-1542.

9. Badalians Gholikandi G, Jamshidi S, Ebrahimzade V: The response of anaerobic baffled reactor in various operational conditions. Int J Wastewater Treat Green Chem 2011, 2:1-10.

10. Badalians Gholikandi G, Jamshidi S, Hazrati H: Optimization of anaerobic baffled reactor (ABR) wastewater treatment system using artificial neural network. Environ Eng Manage. in press.

11. Bodkhe SY: A modified anaerobic baffled reactor for municipal wastewater treatment. Environ Manage 2009, 90:2488-2493.

12. Feng HJ, Hu LF, Mahmood Q, Qiu CD, Fang CG, Shen DS: Anaerobic domestic wastewater treatment with bamboo carrier anaerobic baffled reactor. Int Biodeterior Biodegrad 2008, 62:232-238.

13. Chang JJ, Wu SQ, Dai YR, Liang W, Wu ZB: Treatment performance of integrated vertical-flow constructed wetland plots for domestic wastewater. Ecol Eng 2012, 44:152-159.

14. Kaseva ME: Performance of a sub-surface flow constructed wetland in polishing pre-treated wastewater - a tropical case study. Water Res 2004, 38:681-687.

15. Mbuligwe SE: Comparative effectiveness of engineered wetland systems in the treatment of anaerobically pre-treated domestic wastewater. Ecol Eng 2004, 23:269-284.

16. Singh S, Haberl R, Moog O, Shrestha RR, Shrestha P, Shrestha R: Performance of an anaerobic baffled reactor and hybrid constructed wetland treating high-strength wastewater in Nepal - a model for DEWATS. Ecol Eng 2009, 35:654-660.

17. Landmeyer JE: Introduction to Phytoremediation of Contaminated Groundwater. New York: Springer; 2012.

18. Stottmeister U, Wiebner A, Kuschk P, Kappelmeyer U, Kastner M, Bederski O, Muller RA, Moormann $\mathrm{H}$ : Effects of plants and microorganisms in 
constructed wetlands for wastewater treatment. Biotechnol Adv 2003, 22:93-117.

19. Valipour A, Azizi S, Raman VK, Jamshidi S, Hamnabard N: The comparative evaluation on the performance of two phytoremediation systems for domestic wastewater treatment. Environ Sci Eng. in press.

20. Arivoli A, Mohanraj R: Efficacy of Typha angustifolia based vertical flow constructed wetland system in pollutant reduction of domestic wastewater. Int J Environ Sci 2013, 3:1497-1508.

21. Valipour A, Raman VK, Ghole VS: A new approach in wetland systems for domestic wastewater treatment using Phragmites sp. Ecol Eng 2009, 35:1797-1803.

22. Valipour A, Raman VK, Ghole VS: Application of patent bio-rack wetland system using Phragmites sp. for domestic wastewater treatment in the presence of high total dissolved solids (TDS) and heavy metal salts. Environ Sci Eng 2011, 53:281-288.

23. Valipour A, Raman VK, Badalians Gholikandi G: Comparative evaluation on the performance of bio-rack and shallow pond systems for domestic wastewater treatment. Environ Sci Eng 2012, 54:453-462.

24. Wang J, Zhang L, Lu S, Jin X, Gan S: Contaminant removal from low-concentration polluted river water by the Bio-rack wetlands. Environ Sci 2012, 24:1006-1013.

25. Wang J, Zhang LY, Lu SY, Gan S, Jin XC: Removal of $N$ and $P$ from river water treated by the bio-rack wetland planted with Thalia dealbata and Acorus calamus Linn. J Jilin Univ (Earth Sci Ed) 2012, 42:408-414.

26. Marchand L, Nsanganwimana F, Oustrière N, Grebenshchykova Z, Lizama-Allende K, Mench M: Copper removal from water using a bio-rack system either unplanted or planted with Phragmites australis, Juncus articulatus and Phalaris arundinacea. Ecol Eng 2014, 64:291-300.

27. Tangahu BV, Abdullah SRS, Basri H, Idris M, Anuar N, Mukhlisin M: A review on heavy metals $(\mathrm{As}, \mathrm{Pb}$, and $\mathrm{Hg}$ ) uptake by plants through phytoremediation. Int J Chem Eng 2011, 2011:1-31.

28. APHA: Standard Methods for the Examination of Water and Wastewater. Washington DC: American Public Health Association; 2005.

29. Costley SC, Wallis FM: Bioremediation of heavy metals in a synthetic wastewater using a rotating biological contactor. Water Res 2001, 35:3715-3723.

30. Kalra YP: Handbook of Reference Methods for Plant Analysis. Florida: CRC Press; 1998.

31. Ge Z, Zhang H, Zhang Y, Yan C, Zhao Y: Purifying synthetic high-strength wastewater by microalgae chlorella vulgaris under various light emitting diode wavelengths and intensities. J Environ Health Sci Eng 2013, 11:1-10.

32. Vymazal J, Kropfelova L: Wastewater Treatment in Constructed Wetlands with Horizontal Sub-surface Flow. Dordrecht: Springer; 2008.

33. Karathanasis $A D$, Potter $C L$, Coyne MS: Vegetation effects on fecal bacteria BOD, and suspended solid removal in constructed wetlands treating domestic wastewater. Ecol Eng 2003, 20:157-169.

34. Marques JJ, Souza RR, Souza CS, Rocha ICC: Attached biomass growth and substrate utilization rate in a moving bed biofilm reactor. Braz $J$ Chem Eng 2008, 25:665-670.

35. Lewandowski Z, Beyenal H: Mass transport in heterogeneous biofilms. In Biofilms in Wastewater Treatment: an Interdisciplinary Approach. Edited by Wuertz S, Bishop P, Wilderer P. London: IWA Publishing; 2003:147-177.

36. Hondulas JL: Treatment of Polluted Water Using Wetland Plants in a Floating Habitat. Gatlinburg, Tennessee: United States Patent: US5337516; 1994.

\section{Submit your next manuscript to BioMed Central and take full advantage of:}

- Convenient online submission

- Thorough peer review

- No space constraints or color figure charges

- Immediate publication on acceptance

- Inclusion in PubMed, CAS, Scopus and Google Scholar

- Research which is freely available for redistribution

Submit your manuscript at www.biomedcentral.com/submit
Ciomed Central 